\title{
Compatibility of the digital design of prosthetic crowns with restorations made in the technology of selective laser sintering of metal powders
}

\section{Zgodność cyfrowego projektu koron protetycznych z uzupelnieniami wykonanymi w technologii laserowego selektywnego spieku proszków metalowych}

\author{
Daniel Surowiecki ${ }^{1}$,Marcin Szerszeñ ${ }^{1}$, Kamila Wróbel-Bednarz', \\ Agata Walczyk ${ }^{2}$ \\ ${ }^{1}$ Katedra Protetyki Stomatologicznej, Warszawski Uniwersytet Medyczny \\ Chair of Prosthodontics, Medical University of Warsaw \\ Kierownik: prof. dr hab. n. med. Elżbieta Mierzwińska-Nastalska \\ ${ }^{2}$ Studenckie Koło Naukowe przy Katedrze Protetyki Stomatologicznej, Warszawski Uniwersytet Medyczny \\ Students' Research Group, at the Chair of Prosthodontics, Medical University of Warsaw
}

KEY WORDS:

digital dentistry, crown preparation, accuracy

\section{Summary}

Introduction. Development of digital imaging, designing and manufacturing techniques have led to the possibility of manufacturing prosthetic restorations without the need for conventional laboratory procedures. One of the methods of production is the technology of laser sintering of metal powders - Direct Metal Laser Sintering (DMLS). With the use of CAD/CAM systems, it can replace the traditional technique of casting the crown substructure with the lost wax technique.

Aim of study. To compare the compatibility of the digital design of prosthetic crowns with restorations made with the use of laser sintering technology (DMLS).

Materials and methods. The study material consisted of five prosthetic crowns made in DMLS technology based on the intraoral scan. Internal surfaces of the restorations were scanned using a laboratory scanner. The obtained point clouds in the form of a mesh of internal surfaces and crown designs in the form of CAD models were sent to
HASŁA INDEKSOWE:

cyfryzacja, preparacja pod koronę, dokładność

Streszczenie

Wstęp. Rozwój cyfrowych technik obrazowania, projektowania $i$ wytwarzania doprowadzity do możliwości wykonawstwa uzupetnień protetycznych bez konieczności wykorzystania konwencjonalnych technik laboratoryjnych. Jedna z metod wykonawstwa jest technologia laserowego spiekania proszków metali - Direct Metal Laser Sintering (DMLS). Dzięki systemom CAD/CAM może zastapić ona tradycyjna technikę odlewania podbudowy koron metoda traconego wosku.

Cel pracy. Celem pracy byto porównanie zgodności cyfrowego projektu koron protetycznych z uzupetnieniami wykonanymi w technologii spieku laserowego (DMLS).

Material i metoda. Materiat do badań stanowito 5 koron protetycznych, wykonanych $w$ technologii DMLS na podstawie skanu wewnatrzustnego. Wewnętrzne powierzchnie uzupetnień zostaty zeskanowane przy użyciu skanera laboratoryjnego. Uzyskane chmury punktów w postaci siatki powierzchni wewnętrznych oraz projekty 
the GOM Inspect 2018 software. Design matching (CAD models) with scans of their internal surface was made for each crown. In this way, a heat map was obtained, illustrating the deviations between the compared models and meshes.

Results. The first and the fifth crowns were characterized by an average deviation of $0.00 \pm$ $0.03 \mathrm{~mm}$ and $0.00 \pm 0.05 \mathrm{~mm}$, respectively. The highest mean deviation was obtained when the second crown was measured, i.e. $0.03 \pm 0.02$ $\mathrm{mm}$. The highest maximum positive deviation was recorded for the fourth crown, whose value was $0.12 \mathrm{~mm}$, while the largest negative deviation was observed in the first and the fifth crowns - this value was $-0.10 \mathrm{~mm}$.

Conclusion. Analysis of the compatibility of digital designs with ready-made crowns showed that laser sinter technology enables the fabrication of crowns with accuracy corresponding to the presented results. Failure to obtain a statistical constant value of the deviation makes it impossible to determine the error occurring at the stage of manufacturing of the prosthetic restoration in DMLS technology. The application of the described method allows virtual control of the degree of fit of the prosthetic restoration before placing it in the patient's mouth.

\section{Introduction}

The evolution and development of digital imaging, designing and manufacturing techniques (CAD/CAM - Computer Aided Designing/Computer Aided Manufacturing) led to the possibility of producing prosthetic restorations without the necessity of use of conventional laboratory procedures. ${ }^{1}$ Intraoral scanning technology is a dynamically developing method used in dentistry, reflecting the needs of the exact registration of oral tissues, including the prosthetic field. Precise designing and manufacturing of prosthetic koron w postaci modeli CAD przestano do oprogramowania GOM Inspect 2018. Dla każdej korony wykonano dopasowanie projektów (modeli CAD) ze skanami ich powierzchni wewnętrznej. $W$ ten sposób uzyskano mape ciepta, ilustrujaca odchylenia pomiędzy porównywanymi modelami i siatkami.

Wyniki. Korony pierwsza i piata charakteryzowaty się średnia wartościa odchylenia odpowied-

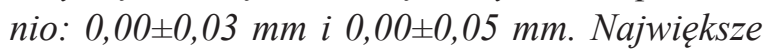
średnie odchylenie uzyskano przy pomiarach

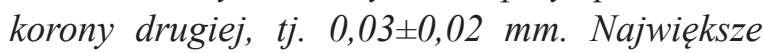
maksymalne odchylenie dodatnie odnotowano $w$ przypadku korony czwartej, którego wartość wyniosta 0,12 mm, natomiast największe odchylenie ujemne charakteryzowato korony pierwsza i piata, wartość ta wyniosta $-0,10 \mathrm{~mm}$.

Wnioski. Analiza zgodności projektów cyfrowych z gotowymi koronami wykazata, że technologia spieku laserowego umożliwia wykonanie koron o doktadności odpowiadającej przedstawionym wynikom. Brak uzyskania statystycznej statej wartości odchylenia uniemożliwia określenie btędu pojawiajacego się na etapie wykonawstwa uzupetnienia protetycznego $w$ technologii DMLS. Zastosowanie opisanej metody umożliwia wirtualna kontrole stopnia dopasowania uzupetnienia protetycznego przed jego umieszczeniem $w$ jamie ustnej pacjenta.

\section{Wstęp}

Ewolucja i rozwój cyfrowych technik obrazowania, projektowania i wytwarzania $(\mathrm{CAD} /$ CAM - Computer Aided Design/ Computer Aided Manufacture) doprowadziły do możliwości wykonawstwa uzupełnień protetycznych bez konieczności wykorzystania konwencjonalnych technik postępowania laboratoryjnego. ${ }^{1}$ Technologia skanowania wewnątrzustnego jest dynamicznie rozwijającą się metodą wykorzystywaną w stomatologii, odpowiadającą na potrzeby dokładnego odwzorowania tkanek jamy ustnej, w tym pola protetycznego. 
restorations is the basis to ensure long-term, durable reconstruction with an appropriate degree of fit. $^{2}$ One of the manufacturing method is the technology of laser sintering of metal powders - Direct Metal Laser Sintering (DMLS). Due to CAD/CAM system it can replace the traditional technique of casting the crown substructure using the lost wax method. Digital impressions and prosthetic field scanning systems have been successively introduced since the 1980 's, ${ }^{3}$ from then on contributing to the development of the socalled "impressionless dentistry" and trying to tackle the disadvantages and drawbacks of the traditional procedure of taking impressions, such as: changing the consistency of the material during setting or displacement of soft tissues under pressure. Digital design systems have additionally enabled the initial three-dimensional visualization of tooth reconstruction, which facilitated patientdoctor-dental technician communication. The additional attribute of digital dentistry protocols is limiting the possibility of making an error inherent in human nature. ${ }^{4}$ Fixed prosthetic restorations made using both laser sintering technology and the conventional method must meet several basic requirements to be fully acceptable. Reports in literature often emphasize the role of marginal fit and matching the crown substructure to the abutment tooth to ensure durability and aesthetics of the restoration. ${ }^{5.6}$ With the development of designing techniques of fixed restorations manufacture in CAD/CAM systems, numerical methods for assessing the accuracy of mapping their shape gained particular importance. Analysis of the digital procedures is the key to understanding the impact of the current digitization trend in prosthodontics. It seems necessary to conduct evaluation of the accuracy of the digital protocols used in the manufacture of restorations.
Precyzyjne zaprojektowanie i wykonanie uzupełnień protetycznych jest podstawą do zapewnienia długoczasowej, trwałej odbudowy o odpowiednim stopniu dopasowania. ${ }^{2}$ Jedną z metod wykonawstwa jest technologia laserowego spiekania proszków metali - Direct Metal Laser Sintering (DMLS), dzięki systemom CAD/CAM może zastąpić ona tradycyjną technikę odlewania podbudowy koron metodą traconego wosku.

Cyfrowe wyciski i systemy skanowania pola protetycznego są sukcesywnie wprowadzane od lat $80 \mathrm{XX}$ wieku ${ }^{3}$ i od tego czasu przyczyniając się do rozwoju tzw. stomatologii bezwyciskowej próbują zmierzyć się z wadami i niedogodnościami tradycyjnego procesu pobierania wycisków, takich jak m.in.: zmiana konsystencji masy podczas wiązania czy przesunięcie tkanek miękkich pod wpływem ucisku. Systemy projektowania cyfrowego umożliwiły dodatkowo wstępną trójwymiarową wizualizację odbudowy zęba, przez co ułatwiły komunikację pacjent lekarz - technik dentystyczny. Dodatkową cechą protokołów cyfrowej stomatologii jest ograniczenie możliwości popełnienia błędu wpisanego w ludzką naturę. ${ }^{4}$ Stałe uzupełnienia protetyczne wytwarzane zarówno z wykorzystaniem spieku laserowego jak i metodą tradycyjną, aby były w pełni akceptowalne, muszą spełniać kilka podstawowych wymagań. W literaturze wielokrotnie podkreślana była rola jaką odgrywają: szczelność brzeżna i dopasowanie podbudowy korony do filaru zębowego, zapewniając jej trwałość i estetykę. ${ }^{5,6}$ Wraz z rozwojem technik projektowania stałych uzupełnień w systemach CAD/CAM szczególne znaczenie zyskują numeryczne metody oceny dokładności odwzorowania ich kształtu. Analiza procedur cyfrowych ma kluczowe znaczenie dla zrozumienia wpływu aktualnego trendu cyfryzacji w dziedzinie protetyki stomatologicznej. Niezbędnym więc wydaje się przeprowadzanie ewaluacji dokładności zastosowanych protokołów cyfrowego wytwarzania. 


\section{Aim of study}

The aim of the study was to compare the compatibility of the digital design of prosthetic crowns with restorations made with the use of laser sintering of metal powders technology (DMLS).

\section{Material and methods}

The study material consisted of five prosthetic crowns made on extracted human molars and premolars. The teeth were extracted because of orthodontic indications, then disinfected using $5 \% \mathrm{NaOCl}$ and placed in wax matrices (Fig. 1). The teeth were prepared for prosthetic crowns made with chamfer type in accordance with applicable rules. Prepared abutment teeth were subjected to a scanning process using a Trios intraoral scanner III (3Shape, Denmark). The STL (Stereolithography) models obtained from the scan were sent to technical laboratory, in which metal substructure of crowns was designed for each abutment tooth in Exocad Dental CAD (Exocad GmbH, Germany) (Fig. 2). The next stage was the production of the restorations with the method of selective laser sintering using an EOS M100 production machine (EOS GmbH, Germany) from chromium cobalt powder SP2 intended for prosthetic applications. The internal surfaces of the prosthetic crowns were covered with anti-reflection coating and then scanned using a laboratory scanner Zirkonzahn S600 (Zirkonzahn, Germany). Obtained point clouds in the form of a mesh of internal surfaces and designs of crowns in the form of CAD models were sent to the GOM Inspect software 2018 (GOM GmbH, Germany). Pre-fitting was performed for each crown designs (CAD models) with scans of their internal surface (Fig. 5). Next, the area of analysis was determined within which the fitting test was performed with the Local Best Fit command (Fig. 6). In this way, heat maps were obtained, showing deviations

\section{Cel pracy}

Celem pracy było porównanie zgodności cyfrowego projektu koron protetycznych z uzupełnieniami wykonanymi w technologii spieku laserowego (DMLS).

\section{Materiał i metoda}

Materiał do badań stanowiło 5 koron protetycznych wykonanych na usuniętych ludzkich zębach trzonowych i przedtrzonowych. Zęby poddano ekstrakcji ze wskazań ortodontycznych, następnie zdezynfekowano przy użyciu $5 \% \mathrm{NaOCl}$ i umieszczono w woskowych matrycach (ryc. 1). Preparację zębów pod korony protetyczne wykonano ze stopniem typu chamfer zgodnie z obowiązującymi zasadami. Opracowane zęby filarowe poddano procesowi skanowania przy użyciu skanera wewnątrzustnego Trios III (3Shape, Dania). Modele STL (Stereolithography) uzyskane na podstawie skanowania wysłano do pracowni technicznej, w której zaprojektowano podbudowy metalowe koron dla każdego zęba filarowego w oprogramowaniu Exocad Dental CAD (Exocad $\mathrm{GmbH}$, Niemcy) (ryc. 2). Kolejnym etapem było wykonanie gotowych uzupełnień metodą selektywnego spiekania laserowego, przy użyciu maszyny produkcyjnej EOS M100 (EOS $\mathrm{GmbH}$, Niemcy) z proszku chromokobaltowego SP2 przeznaczonego do zastosowań protetycznych. Wewnętrzne powierzchnie koron protetycznych zostały pokryte powłoką antyreflesyjną, a następnie zeskanowane przy użyciu skanera laboratoryjnego Zirkonzahn S600 (Zirkonzahn, Niemcy).

Uzyskane chmury punktów w postaci siatki powierzchni wewnętrznych oraz projekty koron w postaci modeli CAD przesłano do oprogramowania GOM Inspect 2018 (GOM GmbH, Niemcy). Dla każdej korony wykonano dopasowanie wstępne projektów (modeli CAD) ze skanami ich powierzchni wewnętrznej (ryc. 5). 


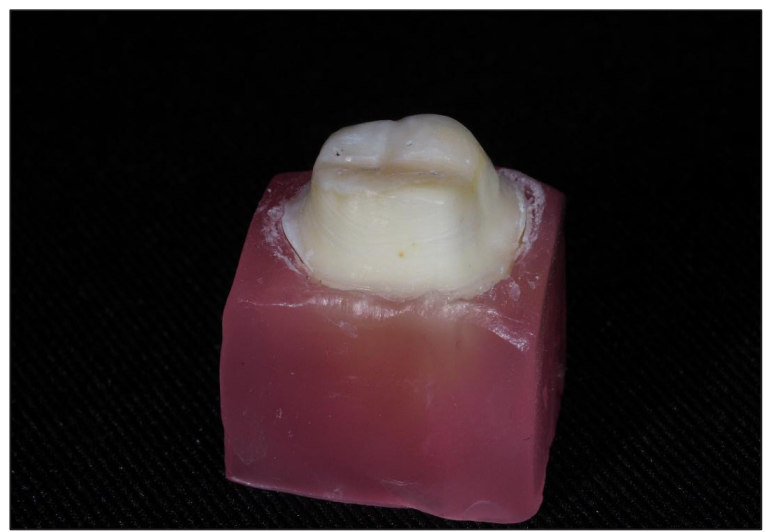

Fig. 1. Prepared abutment tooth, placed in wax matrix.

Ryc. 1. Opracowany filar umieszczony w woskowej matrycy.

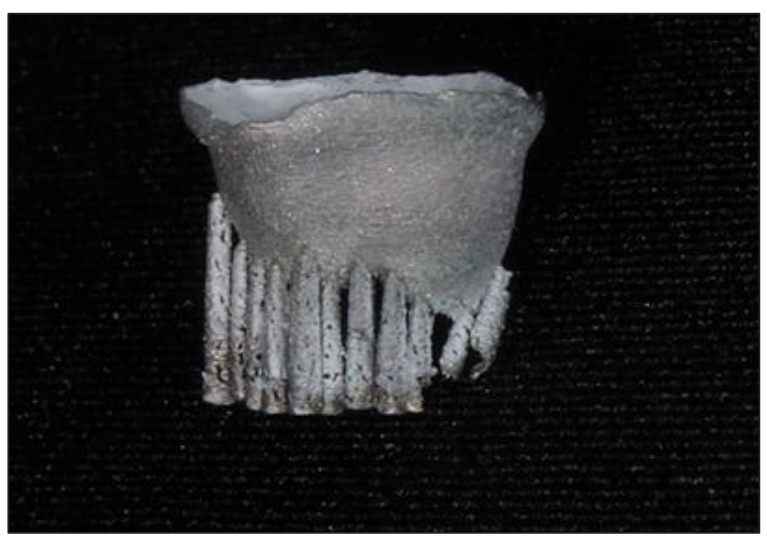

Fig. 3. DMLS crown.

Ryc. 3. Korona DMLS.

between compared models and meshes. A total of fifty measurement points were randomly selected for each crown. The results of these measurements were statistically analysed in the form of descriptive statistics, Shapiro-Wilk test verified the normality of the distribution, then Kruskal-Wallis test between individual variables of each crown. For statistical tests, a significance level of $\alpha=0.05$ was assumed.

\section{Results}

A total of 250 measuring points were obtained for five crowns, fifty for each crown. The values of descriptive statistics for individual

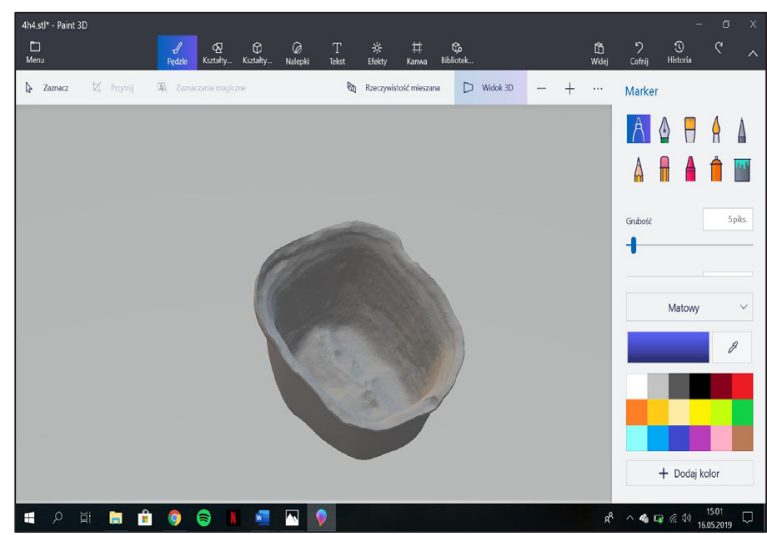

Fig. 2. Project of the substructure of the crown. Ryc. 2. Zaprojektowana podbudowa korony protetycznej.

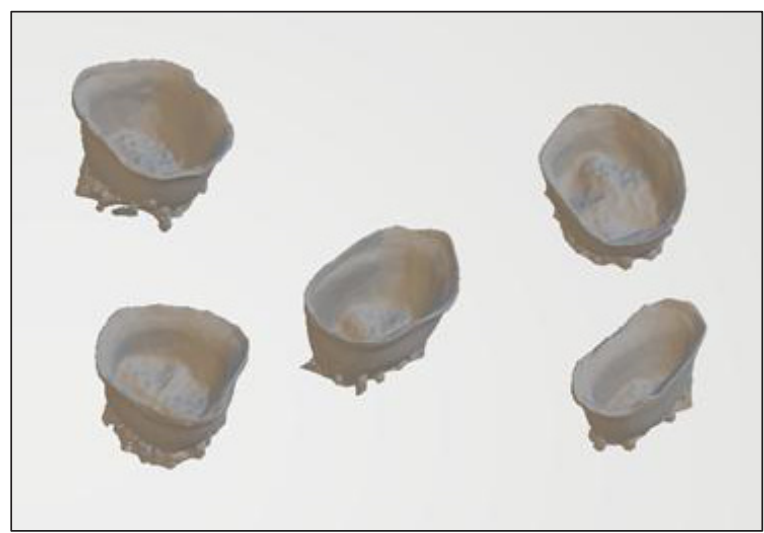

Fig. 4. Scanned crowns.

Ryc. 4. Zeskanowane korony protetyczne.

Następnie określono obszar poddany analizie, w obrębie którego wykonano badanie nadając komendę Local Best Fit (ryc. 6). W ten sposób uzyskano mapę ciepła, ilustrującą odchylenia pomiędzy porównywanymi modelami i siatkami, pochodzącymi ze skanowania laboratoryjnego. Losowo wybrano 50 punktów pomiarowych dla każdej korony. Wyniki tych pomiarów poddano analizie statystycznej w postaci statystyki opisowej, testu Shapiro-Wilka, w celu weryfikacji normalności rozkładu, a następnie testu Kruskala-Wallisa pomiędzy poszczególnymi zmiennymi każdej korony. Dla testów statystycznych przyjęto poziom istotności $\alpha=0,05$. 


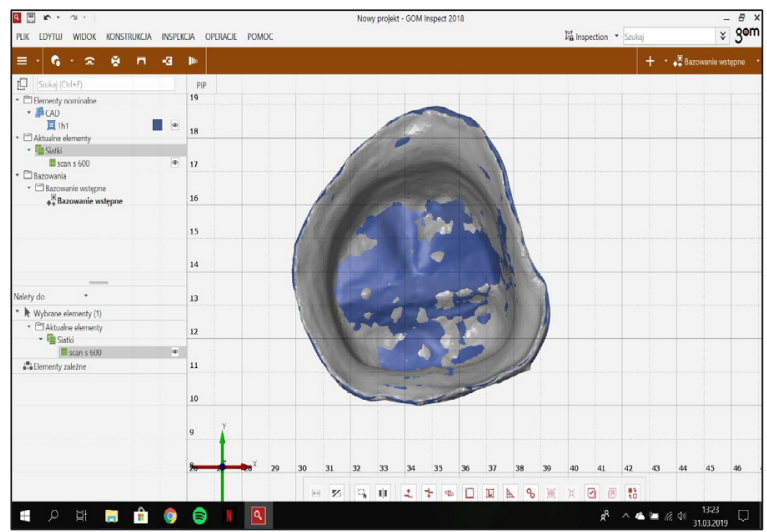

Fig. 5. Prealigment in GOM Inspect software.

Ryc. 5. Bazowanie wstepne w oprogramowaniu GOM Inspect.

crowns are presented in Table 1. The first and the fifth crown had an average deviation of 0.00 $\pm 0.03 \mathrm{~mm}$ and $0.00 \pm 0.05 \mathrm{~mm}$, respectively, which was the smallest detected measurement difference. The highest mean deviation was obtained when measuring the second crown, i.e. $0.03 \pm 0.02 \mathrm{~mm}$. The highest maximum positive deviation was recorded in the case of the fourth crown, whose value was $0.12 \mathrm{~mm}$, while the largest negative deviation was recorded for the first and the fifth crown - this value was -0.10 $\mathrm{mm}$. The distribution of examined deviations is presented in Figures 7-11. After fulfilling the conditions for the statistical test, the Kruskal-Wallis test was carried out, obtaining

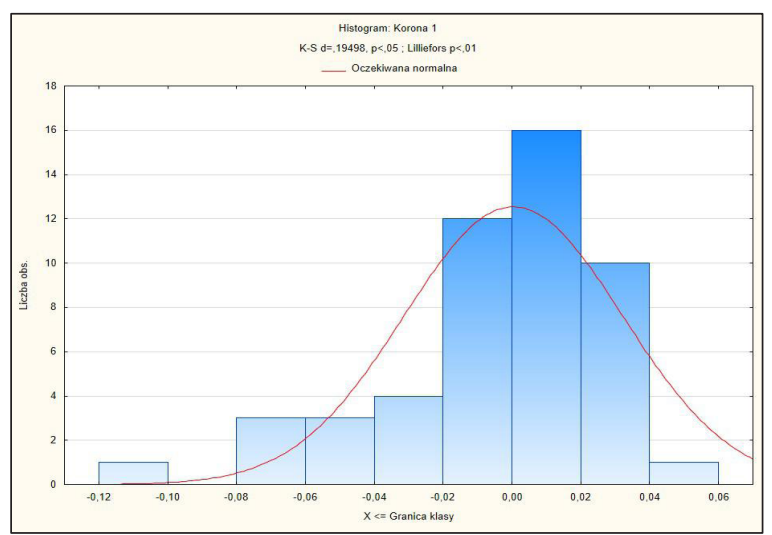

Fig. 7. Distribution of deviations - crown 1.

Ryc 7. Rozkład odchyleń dla korony pierwszej.

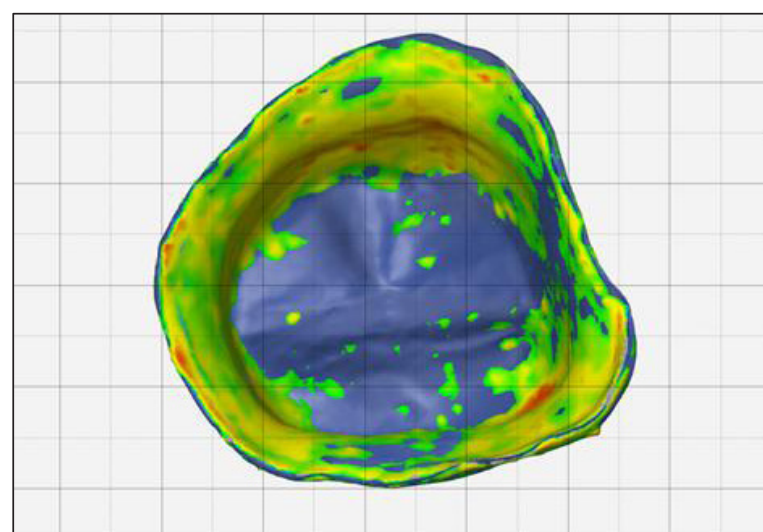

Fig. 6. Local Best Fit in GOM Inspect software.

Ryc. 6. Komenda Local Best Fit w oprogramowaniu GOM Inspect.

\section{Wyniki}

Dla 5 koron uzyskano łącznie 250 punktów pomiarowych, po 50 dla każdej korony. Wartości statystyki opisowej dla poszczególnych koron przedstawiono w tabeli 1 . Korony pierwsza i piąta charakteryzowały się średnią wartością odchylenia odpowiednio: $0,00 \pm 0,03$ $\mathrm{mm}$ i $0,00 \pm 0,05 \mathrm{~mm}$, co stanowiło najmniejszą wykrytą różnicę pomiarową. Największe średnie odchylenie uzyskano przy pomiarach korony

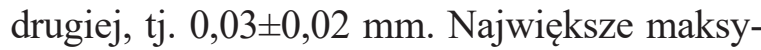
malne odchylenie dodatnie odnotowano w przypadku korony czwartej, którego wartość wyniosła $0,12 \mathrm{~mm}$, natomiast największe odchylenie ujemne charakteryzowało korony pierwszą i piątą, wartość ta wyniosła $-0,10$ mm. Rozkład badanych odchyleń przedstawiono na rycinach 7-11.

Po spełnieniu warunków dla testu statystycznego przeprowadzono test Kruskala - Wallisa, uzyskując wynik $\mathrm{p}=0.0002$. Wykazano istotne statystycznie różnice między grupami koron 1-5. Przeprowadzono opisową analizę „map ciepła”, dla każdej korony, widocznych na rycinach 12-16. W przypadku każdej korony zwraca uwagę obecność obszarów, charakteryzujących się ujemnym odchyleniem (kolor niebieski) na powierzchni żującej koron protetycznych. Ściany boczne oraz obszar w okolicy 
Ta ble 1 . The values of descriptive statistics for individual crowns

\begin{tabular}{|c|c|c|c|c|c|}
\hline & $\mathrm{N}$ & Mean & Minimum & Maximum & $\begin{array}{c}\text { Standard } \\
\text { deviation }\end{array}$ \\
\hline Crown 1 & 50 & 0,00 & -0.10 & 0,05 & 0,03 \\
\hline Crown 2 & 50 & 0,03 & $-0,01$ & 0,08 & 0,02 \\
\hline Crown 3 & 50 & 0,01 & $-0,06$ & 0,06 & 0,03 \\
\hline Crown 4 & 50 & 0,02 & $-0,09$ & 0,12 & 0,04 \\
\hline Crown 5 & 50 & 0,00 & $-0,10$ & 0,09 & 0,05 \\
\hline
\end{tabular}

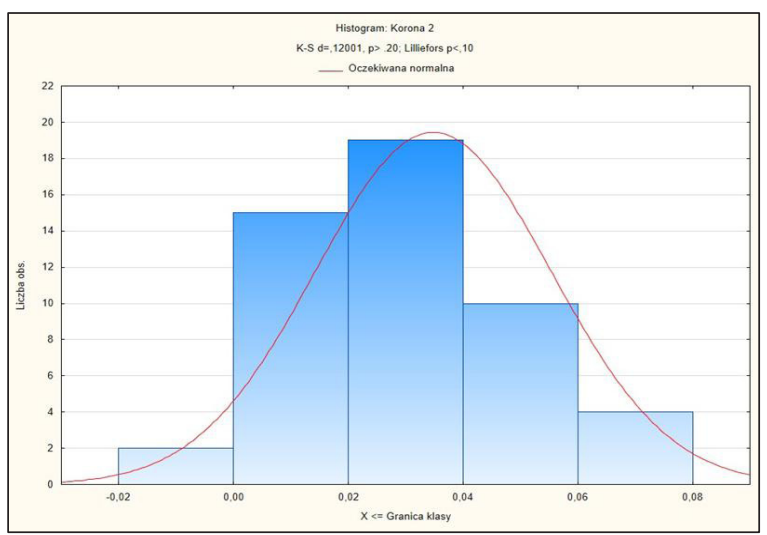

Fig. 8. Distribution of deviations - crown 2. Ryc 8. Rozklad odchyleń dla korony drugiej.

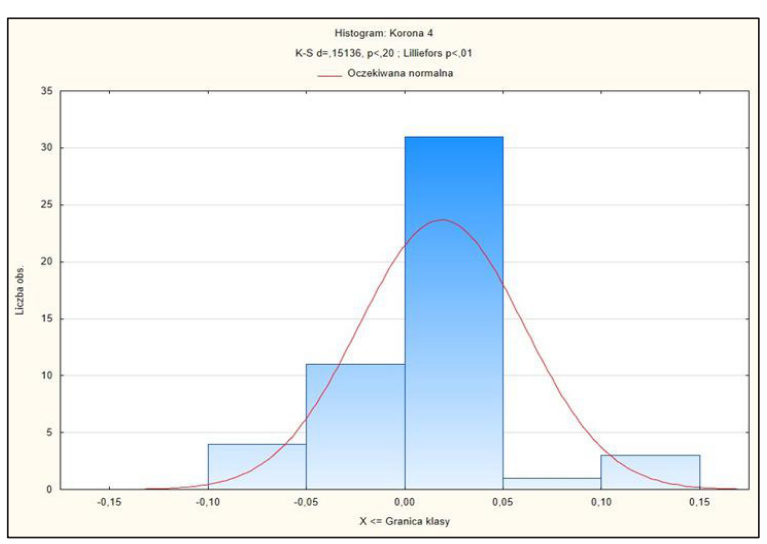

Fig. 10. Distribution of deviations - crown 4. Ryc 10. Rozklad odchylen dla korony czwartej.

a result of $\mathrm{p}=0.0002$. Statistically significant differences were found between crown groups 1-5. A descriptive analysis of "heat maps" was performed for each crown, shown in Figures 12-16. For each crown, the presence of areas

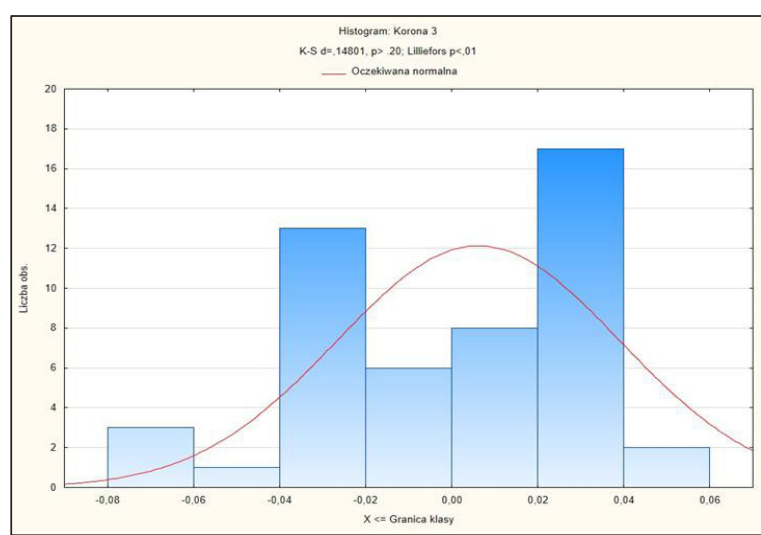

Fig. 9. Distribution of deviations - crown 3. Ryc 9. Rozktad odchyleń dla korony trzeciej.

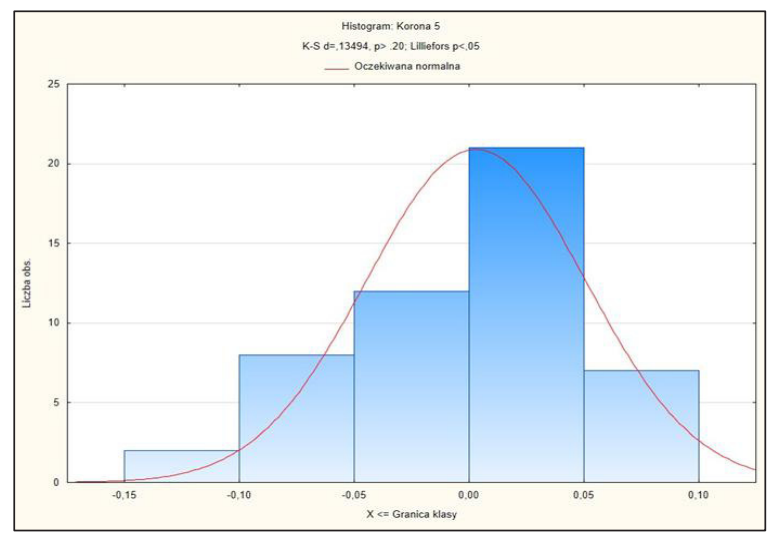

Fig. 11. Distribution of deviations - crown 5. Ryc 11. Rozklad odchylen dla korony piątej.

stopnia charakteryzują się znaczną obecnością obszarów o najmniejszym odchyleniu, tj. zbliżonych do zera (kolor zielony). Wyjątek stanowi korona pierwsza, w której ujemne wartości odnotowano również w okolicy stopnia. 


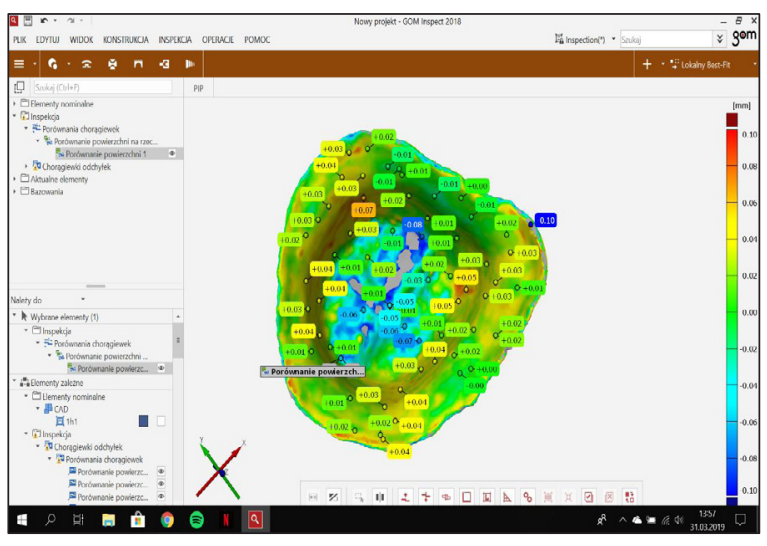

Fig. 12. Heat map - crown 1.

Ryc. 12. Mapa ciepła korona pierwsza.

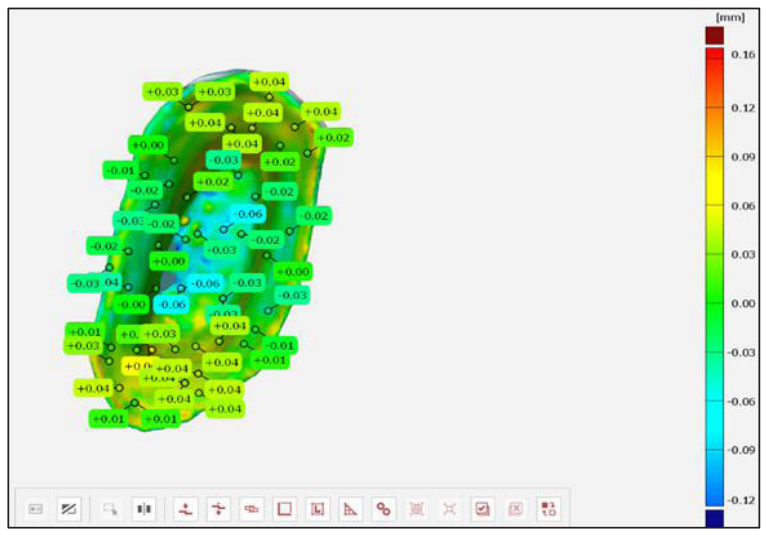

Fig. 14. Heat map - crown 3.

Ryc. 14. Mapa ciepła korona trzecia.

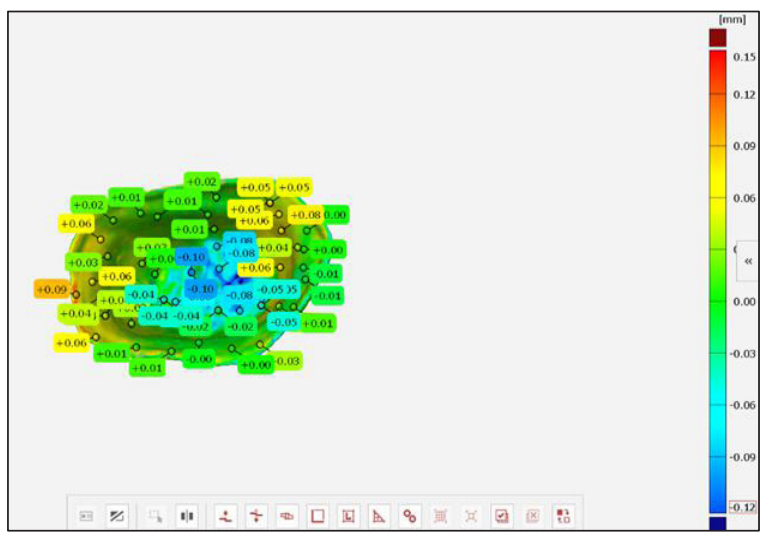

Fig. 16. Heat map - crown 5.

Ryc. 16. Mapa ciepta korona piata.

with a negative deviation (blue) on the chewing surface of the prosthetic crowns is noteworthy. The side walls and the area around the step are characterized by a significant presence of areas

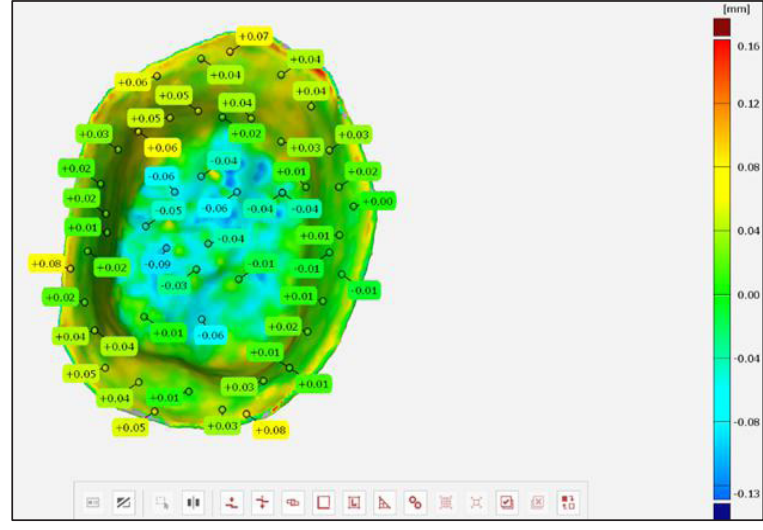

Fig. 13. Heat map - crown 2.

Ryc. 13. Mapa ciepta korona druga.

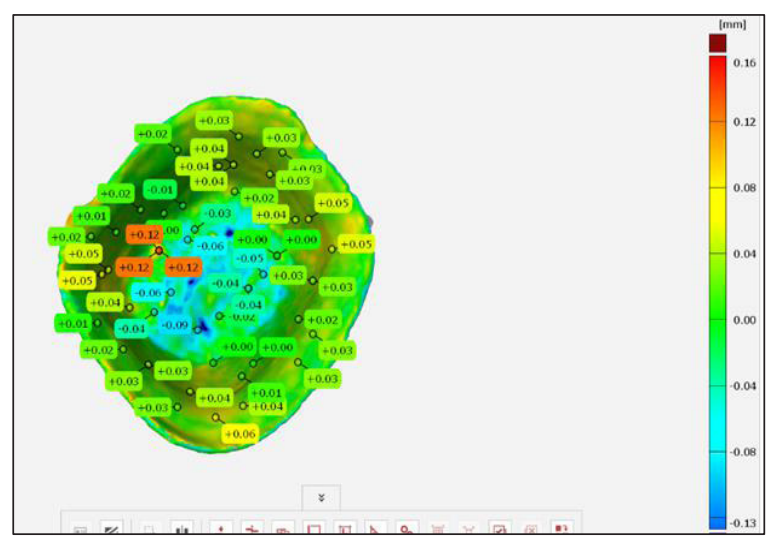

Fig. 15. Heat map - crown 4.

Ryc. 15. Mapa ciepla korona czwarta.

\section{Dyskusja}

Cyfrowe protokoły postępowania są bardzo szybko rozwijającą się domeną nowoczesnej stomatologii, odpowiadającą na potrzeby procesu terapeutycznego. Dokładna adaptacja na poziomie powierzchni nośnej zęba jest niezbędna do zapewnienia trwałej odbudowy protetycznej. Precyzja wykonania i m.in. szczelność brzeżna korony musi być rzetelnie oceniona, ze względu na negatywne skutki, które może spowodować jej brak. Należą do nich: 
with the smallest deviation, i.e. close to zero (green). The exception is the first crown, in which negative values were also noted around the step.

\section{Discussion}

Digital protocols are a rapidly growing domain of modern dentistry, meeting the needs of the therapeutic process. Accurate adaptation at the level of the tooth's supporting surface is necessary to ensure permanent prosthetic reconstruction. Precision of the procedure and the marginal fit of the crown must be reliably assessed, due to the negative effects that their lack may cause. These include: tooth sensitivity, loss of sealing, periodontal disease, secondary caries or alveolar bone atrophy. ${ }^{7,8}$

$\mathrm{CAD} / \mathrm{CAM}$ techniques require fewer production steps compared to conventional techniques, and thus ensure greaterindependence from error. It is now also possible to obtain the preliminary three-dimensional visualization of tooth reconstruction, as well as virtually instant reproduction of a project made in the past, which facilitates communication between the doctor and the dental technician's laboratory. Furthermore, digital technology has increased the precision of fitting, and reduced the aesthetic problems that may occur due to the oxidation of metal structures made of chromium-cobalt alloy. ${ }^{9}$ The development of CAD/CAM and 3-D printing systems has led to prosthetic restorations beyond traditional manufacturing methods. Selective Laser Sintering (DMLS) is currently one of the most commonly used additive technologies used in the production of prosthetic reconstructions. The DMLS method can be used to make a metal substructure for a prosthetic restoration by applying powder layers based on a chromium-cobalt alloy to a working platform, and then to selectively sintering subsequent layers of the manufactured element using a laser beam. Currently, this nadwrażliwość zębów, utrata uszczelnienia, choroby przyzębia, próchnica wtórna czy zanik kości wyrostka zębodołowego.7,8

Techniki CAD / CAM zawierają mniej etapów produkcyjnych w porównaniu z konwencjonalnymi technikami i tym samym zapewniają większe uniezależnienie się od błędu. Możliwa stała się również wstępna trójwymiarowa wizualizacja odbudowy zęba, a także praktycznie natychmiastowe odtworzenie projektu wykonanego w przeszłości, co ułatwia komunikację oraz porozumienie między lekarzem protetykiem a laboratorium techniki dentystycznej. Co więcej, technika cyfrowa zwiększyła precyzję dopasowania i ograniczyła problemy estetyczne, mogące mieć miejsce z powodu utleniania konstrukcji metalowych wykonanych ze stopu chromo-kobaltowego. ${ }^{9}$

Rozwój systemów CAD/CAM i druku przestrzennego doprowadziły do wykonywania uzupełnień protetycznych wykraczając poza tradycyjne metody wytwarzania. Selektywne Spiekanie Laserowe (DMLS) jest aktualnie jedną z częściej stosowanych technologii addytywnych wykorzystywanych w wykonawstwie konstrukcji protetycznych. Metodą DMLS można wykonać podbudowę metalową uzupełnienia protetycznego, poprzez naniesienie warstw proszku na bazie stopu chromo-kobaltowego na platformę roboczą, a następnie na selektywnym spiekaniu kolejnych warstw wytwarzanego elementu za pomocą wiązki lasera. Obecnie jest to najdokładniejsza metoda wytwarzania konstrukcji ze stopu Co-Cr. Taka podbudowa ma homogenną strukturę oraz pozbawiona jest niedokładności, jakie mogą wystąpić w uzupełnieniach wytwarzanych tradycyjnymi metodami odlewniczymi. Stopy te sa bardzo twarde, a także odznaczają się wysoką temperaturą topnienia. Ze względu na większą wytrzymałość od stopów szlachetnych mogą być alternatywą zarówno dla stopów niklowych, jak i tych na bazie złota. Zważywszy na dużą odporność na reakcje elektrochemiczne 
is the most accurate method of producing structures from Co-Cr alloy. Such a substructure is homogeneous and is free of inaccuracies that can occur in restorations produced by traditional casting methods. These alloys are very hard and also have a high melting point. Since they have greater strength than precious alloys, they can be treated as an alternative to both nickel- and gold-based alloys. Due to the high resistance to electrochemical reactions and to their biocompatibility, they can be used in the oral environment. The chemical composition of the alloy and its microstructure has a significant effect on corrosion resistance. Chromiumcobalt alloys are more resistant to this type of destruction processes than chromium-nickel alloys and those that have a low content of precious metals in their composition. Among the base alloys, alloys that contain at least $16-17 \%$ chromium have the highest corrosion resistance. ${ }^{10}$ The terminology describing 'fit' and the techniques used for its measurement and evaluation differ significantly in the literature. There are many different places in the space between the tooth and the prosthetic restoration where measurements can potentially be made. The accuracy of mapping should be assessed by fitting or sealing the structure, and at least fifty points on the tooth surface should be assessed. In the literature, there are many various clinically acceptable marginal fit values. McLean et al. suggested the value of $120 \mathrm{um}$ as the limit. ${ }^{11}$ In other sources, the value of $50-100 \mathrm{um}$ is considered optimal. ${ }^{12,13}$ However, for crowns made with the CAD/CAM technique, the border was $40-90 \mu \mathrm{m} .{ }^{14,15}$ According to the literature, a statistically significantly smaller micro-leakage occurs when prosthetic restorations are made with the use of CAD/CAM systems. However, no statistically significant differences were observed between the crowns made of lithium disilicate and chromium-cobalt. ${ }^{15,16}$ One has to bear in mind that the process of standardizing this test may affect the results, because in vitro oraz biozgodność mogą być stosowane w środowisku jamy ustnej. Skład chemiczny stopu oraz jego mikrostruktura mają istotny wpływ na odporność korozyjną. Stopy chromo-kobaltowe są bardziej odporne na tego typu procesy niszczenia od stopów chromo-niklowych oraz tych, które w swoim składzie mają niską zawartość metali szlachetnych. Spośród stopów nieszlachetnych największą odporność na korozję mają stopy, które w swoim składzie zawierają co najmniej $16-17 \%$ chromu. $^{10}$

Terminologia opisująca „dopasowanie” i techniki stosowane do jej pomiaru oraz oceny różnią się znacznie w literaturze. Istnieje wiele różnych potencjalnych miejsc $\mathrm{w}$ przestrzeni pomiędzy zębem a uzupełnieniem protetycznym, gdzie można dokonać pomiarów. Dokładność odwzorowania należy ocenić poprzez dopasowanie lub szczelność konstrukcji, a ocenie powinno podlegać co najmniej 50 punktów na powierzchni zęba. W literaturze podawane są różne klinicznie akceptowalne wielkości szczelności brzeżnej McLean $i$ wsp. jako graniczną podaje wartość $120 \mathrm{um}^{11} \mathrm{w}$ innych źródłach za optymalną uznawana jest wartość 50-100um. ${ }^{12,13}$ Natomiast dla koron wykonanych techniką CAD/CAM uznano granicę 40$90 \mu \mathrm{m} .{ }^{14,15}$ Piśmiennictwo podaje, iż znacząco mniejszy statystycznie mikroprzeciek powstaje, gdy uzupełnienia protetyczne wykonane są przy udziale systemów CAD/CAM. Nie zauważono jednak istotnych statystycznie różnic pomiędzy koronami wykonanymi z dwukrzemianu-litu oraz chromo-kobaltu. ${ }^{15,16}$

Nie należy zapominać, że proces standaryzacji tego badania może mieć wpływ na wyniki, ponieważ badania in vitro nie odtwarzają wszystkich warunków panujących w środowisku jamy ustnej. Zęby z otaczającymi je tkankami stwarzają odmienne warunki podczas preparacji filarów pod uzupełnienia protetyczne czy przeniesienia sytuacji klinicznej za pomocą skanów, co nie zostało ujęte w niniejszym badaniu. ${ }^{17,18}$ 
tests do not reproduce all conditions present in the oral environment. Teeth with surrounding tissues create different conditions during the preparation of the abutments for prosthetic restorations or the transfer of the clinical situation by means of scans, which was not included in this study. ${ }^{17,18}$

\section{Conclusions}

Analysis of the compatibility of digital designs with ready-made crowns revealed that laser sinter technology enables the production of crowns with accuracy corresponding to the presented results. Failure to obtain a statistical constant value of the deviation makes it impossible to determine the error occurring at the stage of manufacturing of the prosthetic restoration in DMLS technology. The application of the described method enables virtual control of the fit of the prosthetic restoration before placing it in the patient's mouth.

\section{Wnioski}

Analiza zgodności projektów cyfrowych z gotowymi koronami wykazała, że technologia spieku laserowego umożliwia wykonanie koron o dokładności odpowiadającej przedstawionym wynikom.

Brak uzyskania statystycznej stałej wartości odchylenia uniemożliwia określenie błędu pojawiającego się na etapie wykonawstwa uzupełnienia protetycznego $\mathrm{w}$ technologii DMLS.

Zastosowanie opisanej metody umożliwia wirtualną kontrolę stopnia dopasowania uzupełnienia protetycznego przed jego umieszczeniem $\mathrm{w}$ jamie ustnej pacjenta.

\section{References / Piśmiennictwo}

1. Christensen GJ: Impressions are changing: deciding on conventional, digital or digital plus in-office milling. J Am Dent Assoc 2009; 140(10): 1301-1304.

2. Birnbaum NS, Aaronson HB: Dental impressions using 3D digital scanners: virtual becomes reality. Compend Contin Educ Dent 2008; 29(8): 494, 496, 498-505.

3. Beuer F, Schweiger J, Edelhoff D: Digital dentistry: an overview of recent developments for $\mathrm{CAD} / \mathrm{CAM}$ generated restorations. $\mathrm{Br}$ Dent J 2008; 204(9): 505-511.

4. Touchstone A, Nieting T, Ulmer N: Digital Transition. The Collaboration Between Dentists and Laboratory Technicians on CAD/ CAM Restorations. J Amer Dent Assoc 2010; 141(Suppl 2): 9-15.
5. Hamza TA, Ezzat HA, El-Hossary MK, Katamish HM, Shokry TE, Rosenstiel SF: Accuracy of ceramic restorations made with two CAD/CAM systems. J Prosthet Dent 2013; 109(2): 83-87.

6. Kim TG, Kim S, Choi H, Lee JH, Kim JH, Moon HS: Clinical Acceptability of the Internal Gap of CAD/CAM PD-AG Crowns Using Intraoral Digital Impressions. Biomed Res Int 2016; 2016: 7065454.

7. Fransson B, Oilo G, Gjeitanger R: The fit of metal-ceramic crowns, a clinical study. Dent Mater 1985; 1(5): 197-199.

8. Yeo IS, Yang JH, Lee JB: In vitro marginal fit of three all-ceramic crown systems. J Prosthet Dent 2003; 90(5): 459-464.

9. Sorrentino R, Leone R, Leuci S, Ausiello P, 
Zarone F: CAD/CAM cobalt-chromium alloy single crowns in posterior regions: 4-year prospective clinical study. J Osseointegr 2017; 9(3): 282-288.

10. Borowicz J, Modzelewska A, Sarna-Boś K, Ropa A: Zastosowanie stopów metali nieszlachetnych w protetyce stomatologicznej. Nowoczesny Technik Dentystyczny 2019; 1: 26-37.

11. McLean JW, von Fraunhofer JA: The estimation of cement film thickness by an in vivo technique. Br Dent J 1971; 131(3): 107111.

12. Hung SH, Hung KS, Eick JD, Chappell RP: Marginal fit of porcelain-fused-to-metal and two types of ceramic crown. J Prosthet Dent 1990; 63(1): 26-31.

13. Holmes JR, Sulik WD, Holland GA, Bayne $S C$ : Marginal fit of castable ceramic crowns. J Prosthet Dent 1992; 67(5): 594-599.

14. Riccitiello F, Amato M, Leone R, Spagnuolo
$G$, Sorrentino $R$ : In vitro Evaluation of the Marginal Fit and Internal Adaptation of Zirconia and Lithium Disilicate Single Crowns: Micro-CT Comparison Between Different Manufacturing Procedures. Open Dent J 2018; 12: 160-172.

15. Raczkiewicz M, Mazurek K, MierzwińskaNastalska E: Porównanie adaptacji brzeżnej stałych uzupełnień ceramicznych wykonanych metodą tłoczenia masy ceramicznej do formy oraz przy użyciu systemu CAD/CAM - przegląd piśmiennictwa. Protet Stomatol 2018; 68(4): 394-405.

16. Yüksel E, Zaimoğlu A: Influence of marginal fit and cement types on microleakage of allceramic crown systems. Braz Oral Res 2011; 25(3): 261-266.

Zaakceptowano do druku: 08.03.2020 r.

Adres autorów: 02-097 Warszawa, ul. Binieckiego 6.

C Zarząd Główny PTS 2020. 